\title{
SPHERE SOVEREIGNTY AND IRREDUCIBILITY: THE AMBIGUOUS USE OF ABRAHAM KUYPER'S IDEAS DURING THE TIME OF APARTHEID IN SOUTH AFRICA
}

Author:

Mark Rathbone

\section{Affiliation:}

Faculty of Economic and

Management Sciences,

North-West University,

Potchefstroom Campus

\section{Correspondence to:}

Mark Rathbone

Email:

mark.rathbone@nwu.ac.za

\section{Postal address:}

Private Bag X6001,

Potchefstroom Campus,

North-West University,

Potchefstroom, 2520,

South Africa

\section{Dates:}

Accepted: 01 Jun. 2015

Published: 01 Sep. 2015

How to cite this article:

Rathbone, M., 2015,

'Sphere sovereignty and

irreducibility:

The ambiguous use

of Abraham Kuyper's

ideas during the

time of apartheid in

South Africa', KOERS

- Bulletin for Christian

Scholarship 80(1), Art.

\#2208, 8 pages. http://

dx.doi.org/10.19108/

koers.80.1.2208

\section{Copyright:}

(C) 2015. The Author(s)

Published under the

Creative Commons

Atribution License.
The purpose of this article is to highlight the notion that the concept of sphere sovereignty as postulated by Abraham Kuyper was used in an ambiguous if not invidious manner in the history of South Africa, specifically during the time of apartheid. On the one hand, it is associated with the justification of apartheid, which is particularly evident in the document Human relations and the South African scene in the light of Scripture (1976). On the other hand, it is also associated with Black Liberation Theology, specifically by Alan Boesak, who resisted apartheid. The problem is that both these perspectives reduce the complexity of reality to race. According to Kuyper sphere sovereignty meant that no aspect of reality could be an absolute point of departure to structure the whole and each aspect is sovereign in its own domain. Thus, race or any other aspect cannot be the norm to structure reality. The unity and the structure of creation are located in God as creator of all reality. It is precisely this irreducible perspective of Kuyper that can be beneficial for postapartheid South Africa because it views reality as a complex connectivity.

Key concepts: Abraham Kuyper, Sphere sovereignty, Irreducibility, Apartheid, Black Theology

Die doel van hierdie artikel is om aan te dui dat die konsep sfeersoewereiniteit soos gepostuleer deur Abraham Kuyper op 'n dubbelsinnige manier gebruik is in die geskiedenis van SuidAfrika, spesifiek gedurende die tyd van apartheid. Aan die een kant, word dit geassosieer met die regverdiging van apartheid, wat spesifiek uitkomin die dokument Ras, volk en nasie en volkereverhoudinge in die lig van die Skrif (1976). Aan die ander kant word dit geassosieer met Swart Bevrydingsteologie, spesifiek dié van Alan Boesak, wat weerstand teen apartheid gebied het. Die probleem is dat albei hierdie perspektiewe die kompleksiteit van die werklikheid reduseer tot ras. Volgens Kuyper verwys sfeersoewereiniteit daarna dat geen aspek van die realiteit ' $n$ absolute verwysingspunt kan wees vir die strukturering van die geheel nie en elke aspek is soewerein binne sy eie gebied. Daarom kan nie ras of enige ander aspek 'n norm wees om die realiteit te struktureer nie. Die eenheid en struktuur van die realiteit is gesetel in God as skepper van alle dinge. Dit is juis hierdie anti-reduksionistiese perspektief van Kuyper wat voordele mag bied vir post-apartheid Suid-Afrika.

Kernbegrippe: Abraham Kuyper, Sfeersoewereiniteit, Onreduseerbaarheid, Apartheid, Swart Teologie 


\section{INTRODUCTION}

The neo-Calvinist perspective of Abraham Kuyper ${ }^{1}$, among others, played an ambiguous if not invidious role in the history of South Africa, specifically during the time of apartheid. On the one hand, it is associated with the justification of apartheid, which is particularly evident in the document Human relations and the South African scene in the light of Scripture (HR). ${ }^{2}$ On the other hand, it is also associated with Black Liberation Theology, specifically that of Alan Boesak, who resisted apartheid. The problem is that both these perspectives reduce the complexity of reality to race. Thus, in $\mathrm{HR}$, reductionist racial categories function as a justification of apartheid and in the case of Boesak race is used as a means of consciousness-raising and liberation.

The goal of this article is to disentangle Kuyper's concept of sphere sovereignty from these reductions in order to explore the benefits of an anti-reductionist approach for post-apartheid South Africa. Reductionism occurs when the complexity of reality is understood in terms of a single aspect of reality. For example, when a human being is understood as only a biological creature the other aspects of humanity like psychology, spirituality, culture and so forth are not taken into consideration, thus leading to a reduced understanding of the complex nature of human life.

However, for Kuyper sphere sovereignty is rooted in the fact that God is the creator of reality with universal authority over the whole of creation. This universality is balanced by the particularity and uniqueness of each aspect related to all other aspects. Thus, the danger of reductionism is that an aspect of creation can become a universal norm that replaces God, with reason being the primary authority. This tendency reduces the complex nature of reality by using logical deductions from the perspective of a particular aspect to structure the whole, thus creating a false consciousness or false view of reality. This is what happens in the document HR and Boesak's Black Liberation Theology: both reduce reality to race. These racial

The influence of the philosophy of Kuyper on South Africa is directly linked to the influence of the Vrije Universiteit of Amsterdam on theological training in South Africa, specifically through the Theological Seminary in Stellenbosch (Deist 1994:25-27).

The document Human Relations and the South African Scene in the Light of Scripture (1976) was published by the National Book Printers Ltd in Cape Town. The document served as a report at the 1974 Synod of the Dutch Reformed Church on race relations. The official title in Afrikaans is Ras, Volk en Nasie en Volkereverhoudinge in the lig van die Skrif. In October 1974, the General Synod of the Dutch Reformed Church approved and accepted this publication. It developed after the constitution of the first General Synod of the DRC in 1962. A commission was appointed to work on a Scriptural justification of apartheid. At subsequent Synod meetings, reports were rejected because of their controversial nature. In 1970, a new commission under Willem Landman was appointed. The synod of 1974 accepted the document. Many statements were later amended, for example in 1978 paragraph 65, concerning mixed marriages was amended, changing the term 'inadmissible', meaning 'immoral', to 'extremely unwanted' (Loubser 1978:90). reductions undeniably do not reflect Kuyper's philosophy of sphere sovereignty.

In what follows I will discuss Abraham Kuyper's use of the concept sphere sovereignty. Secondly, I will focus on the document HR and the justification of apartheid with special reference to the interpretation of the Tower of Babel narrative and its racial reduction of humankind. Thirdly, the focus shifts to the role of Kuyper in the Black Liberation Theology of Alan Boesak and its reduction of humanity to race as a means of consciousness-raising and liberation. Finally, some implications of the irreducible perspective of Abraham Kuyper for post-apartheid South Africa will be discussed.

\section{ABRAHAM KUYPER, SPHERE SOVEREIGNTY ${ }^{3}$ AND IRREDUCIBILITY}

Kuyper's neo-Calvinism emphasizes the belief that all life emanates from God and is lived under the sovereign rule of $\mathrm{God}^{4}$. This radical position contains a constructive dimension by expanding the influence of the Word of God to all societal dimensions as a function of liberty. In other words, each aspect of reality is free to function according to its constitutional norms without interference from other aspects of reality. This does not mean that aspects of reality are separated from each other. Rather the multiformity of reality is present in every aspect of reality. Kuyper (1956:41) notes that sphere sovereignty highlights the sovereignty of divine ordinances in each sphere of life that functions independently but is irreducibly related to all other aspects through the universal authority of God. Thus, the preservation of the liberty of conscience is attained by the "flourishing of associations in a variety of cultural spheres" (Mouw, 2009:440). Creation consists of diverse aspects with sphere sovereignty ordained and sustained by the inclusivity of the "common grace" of God. Common grace refers to the non-salvific attitude of divine favour that allows for the non-elect to contribute to the positive formation of culture (Mouw, 2009:441). In other words, the totality of creation, with its complexity, is created and constituted by the normative principles for each sovereign sphere by God, thus providing an alternative to humanism (Kuyper, 1943:11).

Kuyper's philosophy resists the humanism of the French Revolution and the reductionism of Enlightenment science by rejecting rationalism and taking its point of departure from the Word of God. Kuyper (1943:87) states that the "French Revolution ignores God. It opposes God. It refuses to recognize a deeper ground of political life than that which is found in nature, that is, in this instance, in man himself". Humanism spilled over in the rationalist and empirical philosophy that developed since Descartes by elevating humanity and creation to a divine status that Kuyper viewed as idolatry (Kuyper, 1943:11). Kuyper (1943:11) viewed the oppositional

The foundation of Kuyper's philosophy is the doctrine of the spheres of sovereignty, a classification system of creation in terms of various related 'levels of existence' (e.g. state, society, and church) that are all under the rule of God (Loubser, 1987:38).

4 An aspect of Kuyper's influence beyond the scholarly realm was the formation of the "Kalvinistiese Bond" (1929), which called for the Christianisation of society (Deist, 1994:136). 
ontological foundations of Calvinism and humanism as the result of a struggle between two life systems wrestling with one another. Kuyper (1943:11) highlights the notion that

...modernism is bound to build a world of its own from the data of nature; while, on the other hand, all those who reverently bend the knee to Christ and worship Him as the Son of the living God, and God himself, are bent upon saving the 'Christian Heritage'. This is the struggle in Europe, this is the struggle in America, and this also, is the struggle for principles in which my own country is engaged.

Thus sphere sovereignty emphasises the fact that the complexity of created reality as well as the norms that govern each aspect is rooted in God as the creator of reality. However, this religious foundation is not a rejection of science and rationality - far from it. The creation of our complex reality by God is the basis of science and therefore Kuyper (1943:110) notes that Calvinism does "foster love for science" because God is the starting point of science; he created the cosmos or material matter which provides the subject matter for scientists. Kuyper (1943:118) exclaims that

Calvinism alone, by means of its dominating principle, which constantly urges us back from the Cross to Creation, and no less by means of its doctrine of common grace, threw open again to science the vast field of the cosmos, now illumined by the Son of Righteousness, of Whom the Scriptures testify that in Him are hid all the treasures of wisdom and knowledge.

In other words, neo-Calvinism does not reject science but resists the faith that empirical reality through rationalism can encompass the totality of creation and truth. According to Kuyper (1943:118) resistance to this idolatry can occur only through submission to the Word of God. The implication is that science is under the command of God and cannot be practised legitimately with modern or other religious presuppositions because they lead to reductionism. In other words, scientific inquiry, in the case of natural sciences and humanities, is encouraged because science is the study of the creation of God. However, the starting point of science, according to Kuyper, is the acceptance that all aspects of creation are inter-related, encompassing and irreducible. The modern faith in empiricism and rationalism denies this inter-related nature of reality. It is therefore in danger of providing a false understanding of reality because of its partial ontology.

Therefore, the concept sphere sovereignty is crucial to understanding Kuyper's philosophy and its influence on the totality of human existence ${ }^{5}$. Dooyeweerd (1979:54) highlights the fact that "Kuyper was the one who first understood sphere sovereignty again as a creation principle and thus fundamentally

Kuyper (1909:35) states: "En zoo volgt dan, dat de menschheid, het menschelijk geslacht of hoe ge de gezamenlijke menschen noemen wilt, in de hoogere saamvatting van hun zedelijke leven niet kunnen optreden dan als saamgevat in een 'Verbond met God'. Het is dit Verbond met God, wat van de menschenmassa eerst zedelijk organisme maakt, en (evenals bij een volk) de 'wet' als een macht op laat treden, den wil in werking zet, en het diepe besef van ondelinge en weerkeerige verantwoordelijkheid doet geboren worden". detached it from the historicistic outlook on human society" (Dooyeweerd, 1979:54). This rejection of the "historicistic" outlook highlights that human history does not follow a process of natural development but is rather closely linked to the normative principles of creation. This normativity is reflected in the different aspects of creation. Dooyeweerd (1979:55) adds that "Kuyper's great achievement was that he grasped the principle of sphere sovereignty as a creational principle" (Dooyeweerd, 1979:55). The creative act of God goes hand in hand with the structuring of creation and society in various aspects with different functions.

The different aspects function according to a normative dimension given by God. This allows for total freedom of expression and authority - sphere sovereignty. It resists reductionism in which any aspect moves beyond its own sphere. Dooyeweerd (1979:41) notes that reductionism is driven by "an idolatrous ground motive". Therefore,

whoever absolutizes one aspect of created reality cannot comprehend any aspect on the basis of its own inner character ... he may discover important moments of truth, he integrates these moments into a false view of the totality of reality" (Dooyeweerd, 1979:41).

It fails to acknowledge the "pluriformity and colorfulness" of reality that is unified in God (Dooyeweerd, 1979:42). The unity ${ }^{6}$ of aspects becomes clear in the "universal coherence and interconnection" that is present in the "structure of each aspect" (Dooyeweerd, 1979:45). There is a "root unity in the religious focus of existence: the heart, soul, or spirit, where it is impossible to flee from God" (Dooyeweerd, 1979:45). In other words, "sphere universality" emerges through the universal coherence contained in the own particular structure (Dooyeweerd, 1979:46). Sovereign spheres emphasize the inter-connected complexity of reality unified in God.

An obvious problem of sphere sovereignty is that it is rooted in the order of creation that leads to a religious antithesis ${ }^{7}$ separation between believers and non-believers. Although Kuyper (1943:118) attempts to address this criticism by the notion of common grace that includes all creation, the problem is that it may lead to the construction of an "idealistic, organic analogy between Creator and creation", according to Naudé (2005:162). In other words, the premise that reality is created by God and that the common grace of God is a means to be inclusive, is viewed by Naudé (2005:162) as an idealistic re-construction of reality with God as the primary source of creation. The danger of this is

6 Loubser (1987:41) notes that the "...living unity, which God desired, had to be born from an inner conviction. This unity had to grow out of the diversity of peoples and generations".

7 It is a "principle demarcation line in temporal life" and not limited to scientific inquiry but open to all people because it focuses on the "religious direction of our life" (Dooyeweerd, 1979:5). Spiritual renewal in depth must be the focus - "where one can no longer escape oneself" (Dooyeweerd, 1979:6). It is a "way of self-examination and not abstract theoretical inquiry" (Dooyeweerd, 1979:6). 
that common grace ${ }^{8}$ may become a theoretical concept that has no relevance for practical reality, thus polarizing reality and society.

To conclude, it is clear that sphere sovereignty resists the tendency to reduce reality. It rather highlights the interconnectedness and complexity of reality that is irreducible and unified in the context of the creative act of God. However, the concept sphere sovereignty is not without problems and misinterpretations specifically in South Africa during the time of apartheid. Sphere sovereignty could well and did result in the pillarization of society along religious lines. But in South Africa, it was its ambiguous role and racial absolutes, and not specifically religious pillarization, that were problematic. This ambiguous use of Kuyper's conception of sphere sovereignty will be explored in section three and four.

\section{SPHERE SOVEREIGNTY AND APARTHEID}

One of the confusing aspects of Kuyperian sphere sovereignty and the universal authority of God in South Africa during the time of apartheid is the uncertainty whether Kuyper understood race as a sovereign sphere. Mouw (2009:443) notes that this uncertainty coupled with Kuyper's Eurocentric view of Africa as "bereft of any impulse for higher life" may explain the elevation of race as a "Kuyperian sphere". This negative reference to Africa can easily be interpreted as representing a qualitative differentiation between races in which Europeans are perceived as being culturally more superiority and refined than Africans. Thus, suggesting that race is a sovereign sphere with different races evolving and existing independent from each other. The implication of this, according to Loubser (1987:39), is that in

South Africa each ethnic group was seen as an organism which formed part of the body of humanity. As an organism, a people had a rhythm and a law of its own as expressed by its language, history, biological composition and locality. Each group was seen as a collective whole, which was supposed to evolve harmoniously from its origin; it was thus sovereign and directly responsible to God, for its own household.

Mouw (2009:442) notes that

the architects and enforcers of the deep injustices of South African apartheid not only professed a Calvinist theology, they often made their case for the segregationist civil order by appealing directly to tenets associated with Kuyperian neo-Calvinism.

In other words, Kuyper's sphere sovereignty, amongst other influences ${ }^{9}$, became associated with apartheid. The problem is

8 It refers to the "religious unity of humankind....religious determinedness of thought" that places all humanity under the general grace of God - Gratia communis (Geertsema, 1987:152-153)

Deist (1994:25-30) highlights that Kuyperism, romanticism, fundamentalism and racism were some of the salient influences on the development of apartheid. that the focus on race became a structuring principle for society, thus a clear departure from the irreducibility of Kuyper's sphere sovereignty. This reductionist view of race is evident in the document HR.

The irreducibility of Kuyper's sphere sovereignty and the universal authority of God were compromised with the rise of apartheid in South African because reality was reduced to race. This reduction is clear in the document HR (1976). The aim of the document was to provide a biblical justification for apartheid. The document is therefore also referred to by some as the Apartheid Bible of the Dutch Reformed Church, thus, highlighting the Calvinist and Kuyperian ${ }^{10}$ roots of the document as a normative principle for life. It is therefore stated in HR (1976:7) that in the consideration of “...relations between races and peoples, the Church of Jesus Christ must accept the Word of God as premise and norm". Although reference is made to various biblical texts, Bax (1983:117) notes that The Tower of Babel narrative (Genesis 11:1-9) is the "key Scriptural passage". In what follows the focus will shift to this biblical text and its racial reductionism.

\subsection{The Tower of Babel narrative and apartheid}

The main thrust of the interpretation of the Tower of Babel narrative is the arrogance of the descendants of Noah (Genesis 10 and 9), who disobeyed God's command to replenish the earth (HR 1976:16). After the traumatic events of the flood, the descendants of Noah sought security in fame associated with technological advancement and conformity. Conformity was expressed in their unity and one means of communication. According to HR (HR 1976:16)

...from the reckless arrogance that is evident in their desire to make a name for themselves, the deliberate concentration on one spot was in conflict with God's command to replenish the earth (Gen 1:28; 9:1,7).

God intervenes and disperses the people by confusing their one language. HR (1976:16) states that their

....one language was split up into a diversity of languages, with the result that a communication crisis developed and it was impossible for them to associate meaningfully with one another. The result gives evidence of God's intention as far as they were concerned: 'So the Lord scattered them abroad from thence upon the face of the earth' (v8 \& 9).

In other words, with the confusion of language the unity of the people is ruptured and they disperse. Thus, through the intervention of God the people fulfil the command of God to replenish the earth.

The rebellion of the people goes much deeper than defying a command by God, according to HR (1976:17). It is an attempt

\footnotetext{
10 Kuyper (1909:168) writes: “...de Heilige Schrift selve, in haar geheel, naar vorm en inhoud, is het Woord des Heeren, is de geboekstaafde getuienis van den levenden God".
} 
to be a display of human power as the unifying principle of creation instead of God. The building of the tower highlights human disobedience and resistance to the creational order of God. It is stated in HR that diversity was implicit in the fact of creation as the cultural imperative (HR 1976:17). The implication, according to $\mathrm{HR}$, is that the sovereignty of each race is an aspect of reality. This is a normative aspect of creation legitimized by the command of God that the inhabitants of Shinar rebelled against. Thus, the Tower of Babel narrative is a warning that denial of this fact is to side with the tower builders (HR 1976:18).

In the document race and the divisions between races are absolute and elevated as an overarching principle to be used to structure society according to God's creational order. The confusion of the language of the Tower builders and the dispersion are regarded as a blessing ${ }^{11}$ for humanity because it results in the division of races. In other words, the dispersion is a blessing because it accomplishes the purpose of God, namely that races should function as independent sovereign aspects of reality. The independence of races does not imply that there are no inter-relationships between races. However, the interrelationship is also a divine imperative but of another order in which superior races have a responsibility to develop lesser races (Kinghorn, 1986:96). Kinghorn (1986:96) refers to this responsibility of superior races as the positive ethic of gun-aanander (grant unto others). In the South African context this responsibility was given to the Afrikaner in order to Christianise and develop other races through housing, sanitation, water, medical care and so forth (Kinghorn, 1986:96). The purpose of development is to accomplish the creational order of God in which all nations function as independent sovereign units. Therefore, the dispersion is a blessing for all people as stated in $\mathrm{HR}$

....to arrive at the whole truth in connection with the family of nations, Gen 10 and 11 must be read in conjunction. The progressive differentiation of humanity into peoples and races involved not only a curse, but also a blessing, not only judgment on the sinful arrogance of the tower builders of Babel, but also an act of mercy whereby mankind is not only protected from destruction, but God's purpose with the creation of man is achieved (HR 1976:18).

In other words, the diversity of races and peoples to which the confusion of tongues contributed, is an aspect of reality which God obviously intended for this dispensation (HR 1976:18). Thus, the only unity the document subcribes to is the spiritual unity of the descendants of Abraham, who is "the spiritual father of a new 'people', one in Christ", and the crucifixion, resurrection and Pentecost (HR 1976:19). Any other unity is viewed as a transgression of the creational norm of racial differentiation and rebellion against God. The tragedy of

11 HR (1976:18) notes: "He who speaks only of blessings and ignores the curse, speaks falsely. But no less falsely speaks he who calls the diversity of peoples according to language, country and nation sinful. It is indicative of the sober balance of the Scripture that it is as far removed from selfish nationalism as from a colourless internationalism'". this interpretation of sphere sovereignty is that the rejection of "forced unity" spills over into "forced separation" based on the divinely ordained norm of difference. In other words, the structure of reality is reduced to race with all the concomitant differential associations of race.

The elevation of race as a creational principle is a clear departure from Kuyper's notion of sphere sovereignty and the universal authority of God. It disregards the intrinsic unity of a multiform reality and the irreducibility of the various dimensions of life. The reason for this is that race is linked to the biotic modality, as not a normative principle of cultural formation. Thus, this reduction is in conflict with the norms of continuity, differentiation and individualization of society and cultural formation within the historical modality (Dooyeweerd, 1979:79).

Further, the irony is that the interpretation of the Tower of Babel narrative in HR is in conflict with the Calvinist tradition (Botman, 2000:3). Calvin (1948:323-324) writes that the sin of the builders is their "obstinacy against God" and a sign of their "headstrong pride, joined with contempt of God". The dispersion was not a simple act by God to replenish the earth but the result of hubris (Calvin, 1948:332). This rebellion against God was communal and resulted in communal judgment - "...all conspired together, so that the blame cannot be cast exclusively upon one, nor even upon a few" (Calvin, 1948:326). In other words, according to Calvin, the sin of the tower builders was pride (hubris) and not disobedience to the command to replenish the earth, as HR suggests.

To summarize, it is clear that HR is a departure from Kuyperian notion of sphere sovereignty through its elevating race to being a key factor of life. This is done in an attempt to biblically justify apartheid. The irony is that the reduction of reality to race was also a means of liberation from the injustice of apartheid as reflected in the work of Boesak.

\section{SPHERE SOVEREIGNTY AND BLACK LIBERATION THEOLOGY}

The injustice of apartheid and its association with Kuyperianism is in stark contrast to Kuyper's outspoken support for social justice. At the Christian Social Congress of 1891 Kuyper states,

...when rich and poor stand opposed to each other, Jesus never takes his place with the wealthier, but always stands with the poorer. He is born in a stable; and while foxes have holes and birds have nests, the Son of Man has nowhere to lay his head...Both the Christ and his disciples after him (just as the prophets before him) invariably took sides against those who were powerful and living in luxury, and for the suffering and oppressed (Botman, 2000:4).

This strong resistance to injustice by Kuyper is clearly linked to his understanding of sphere sovereignty. Injustice and suffering are linked to reductionism that causes imbalances and suffering. In other words, injustice is an indication that the norms of the various aspects of creation that have been constituted by God are transgressed. This reference to justice is 
reflected in the theology of Boesak.

Alan Boesak received his doctoral degree from the Theological Academy of the John Calvin Foundation, Kampen, Netherlands in 1976, titled: Farewell to Innocence: A social-ethical study of black theology and black power, later published by Ravan Press, Johannesburg. His Calvinist roots are clearly reflected in his criticism of the Black Theology of James Cone that gives priority to black experience of injustice as a norm for understanding the Bible. Boesak states that the experience of injustice by black people must be reflected on in the light of the Word of God. Boesak (1977:96) states that

Black Theology must ask whether the actions of blacks for gaining their liberation are in accord with the divine will of God, a thing that can only be done if the Word of God retains its critical and fulfilling function vis-à-vis all human activity.

Thus, the role of the Bible as norm for life and justice, similar to Kuyper, is highlighted by Boesak ${ }^{12}$.

However, there are stark differences between Kuyper's and Boesak's views of justice. For Boesak justice is embodied in blackness that is the foundation of Black Theology. Boesak (1977:113) states:

Indeed, Black Theology is a theology of liberation in the situation of blackness. For blacks, it is the only legitimate way of theologizing - but only within the framework of the theology of liberation.

Thus, for Boesak (1977:16) the “...black experience provides the framework within which blacks understand the revelation of God in Jesus Christ". Boesak (1977:59) therefore highlights the following regarding Black theology in the South African context:

Black theology is how black theologians understand Jesus Christ, the Spirit, the church etc. In relation to justice and liberation and the praxis of this understanding leads inevitably to the mobilization of black people for participation with power in the public arenas of policy and decision-making.

In this regard, expression must also be given to the African culture in Black Theology. Boesak (1977:36) notes that the

...search for true and authentic human identity and liberation is also to acknowledge that one's African-ness is a God given blessing to be rejoiced rather than a fate to be lamented.

Thus, in South Africa the way to resist apartheid is for black African people to affirm their humanity by embracing their of this search going on within many different contexts. Across the world oppressed and hopeful people share the same faith in the one Lord, one baptism and one God who is Father of all, over all, through all and within all (Eph 4:5,6)". blackness. The difference between Kuyper and Boesak is that justice, for Boesak, is the embodiment and articulation of the black experience of injustice as a means of consciousness raising and resistance to apartheid. This limits the view of justice to a particular race and the diverse cultural expression of black people. This is particularly disconcerting in term of the various forms of injustice that people experience. However, for Kuyper justice is a function of irreducibility and the normativity of the creational order.

Later in 1984 Boesak directly relates Black Liberation and Kuyperism in Black and Reformed: Apartheid, Liberation and the Calvinist Tradition (1984). Boesak (1984:97) states that we “... believe passionately with Abraham Kuyper that there is not a single inch of life that does not fall under the Lordship of Christ". Boesak (1984:97) therefore rejects the Dutch Reformed Church's reduction of reality to race in order to justify apartheid by stating that the biblical justification of apartheid is a abuse "of the word of God to suit culture, prejudices, or ideology and is alien to the reformed tradition". However, the way in which Reformed Christians, according to Boesak (1984:94-95), have used the Bible in South Africa to justify Black oppression and white privilege is the very denial of the "Reformed belief in the supremacy of scripture" (Boesak 1984:94-5). Thus, for Boesak, the implication is that "true Reformed theology" is rooted in the transformation and healing of broken and sinful reality. Thus,

Reformed Christians are called on not to accept the sinful realities of the world. Rather we are called to challenge, to shape, to subvert, and to humanize history until it conforms to the norm of the kingdom of God (Boesak, 1984:97).

However, this is in contrast to "white Reformed theology" that has idealized and institutionalized the brokenness of reality as is reflected in the document HR (Boesak, 1984:97). However, Boesak's reference to Kuyper and common grace is limited to a particular racial embodiment of the grace of God as a function of justice. In other words, a racial reference is used to understand how the grace of God is reflected in black liberation.

Boesak affirms the Calvinist and Kuyperian focus on the primacy of the word of God. The Bible is the normative basis for resistance against injustice and the imperative to bring about the transformation of society. The problem is that justice is related to black experience and the black consciousness movement, according to Boesak. In other words, blackness highlights the reduction of reality to race in order to resist white racism and bring about liberation. Thus, Black Liberation reduces the creation of God to race that is clearly a departure from Kuyper's irreducibility of sphere sovereignty.

\section{IRREDUCIBILITY AND POST- APARTHEID SOUTH AFRICA}

The irreducibility of Kuyper's dimensions of reality and experience has important implications for post-apartheid South Africa. In what follows five of these aspects are highlighted:

Firstly, irreducibility accentuates the fact that no aspect of 
reality can be elevated to a principle to structure the whole. This is extremely important in terms of the history of South Africa that had been plagued by the cultural imperialism of the colonial era and the racial supremacy of apartheid. The irony is that de-colonialism and the anti-apartheid movement also used race and culture as points of departure for justice. Thus, irreducibility aims to move beyond absolute notions of justice fixated on cultural and racial aspects that may develop into new forms of oppression and compromise reconciliation in South Africa. In other words, the fact that reality is complex can resist the formation of stagnant cultural boundaries and destructive hierarchical relations. Irreducibility rather stimulates a more inclusive engagement between cultures because sphere sovereignty encompasses the diverse culture, racial and other aspects of humanity that are inter-related and under the universal authority of God.

Secondly, irreducibility of reality highlights that normativity is located in the creational order of God. This is an alternative to the rationalism of the Enlightenment. The implication is that other sources of knowledge associated with aspects like culture, tradition and religion can be accessed. In other words, not only rational and positivistic knowledge can be accommodated. This is extremely important in terms of the cultural and religious diversity of South Africa.

Thirdly, irreducibility resists the formation of nationalist ideologies that may develop as a result of the reduction of reality. The problem is that nationalist ideologies can become totalitarian, thus resulting in a society in which freedom is compromised. Another problem is that the state may lose its focus on the core responsibility to service society. In this regard ideological goals may cloud the purpose of government. Irreducibility resists the "historicistic outlook on human society" that stirs the "national spirit" (Volkgeist) (Dooyeweerd, 1979:54).

Fourthly, irreducibility is a basis for cultural criticism. In some cases cultural practices in South Africa are elevated to a position above criticism, as if culture were a normative aspect of reality. This is problematic in terms of some sexist practices perpetuated by patriarchal structures. Another problem is that certain cultural practices may even be dangerous to the health of people, e.g. initiation rituals that involve young males. It may also exacerbate the spread of disease and viruses, e.g. HIV/ AIDS. Irreducibility highlights the fact that the creation order of God is the only normative basis for society. Thus, it provides a point of departure for cultural critique.

Fifthly, irreducibility resists globalism. Kuyper's legacy also provides a critical tool against globalism - the hegemony of economy and global cultural imperialism. One of the reductions associated with globalization is the fact that culture can be reduced to an economic factor. Comblin (1998:149) notes that

....indigenous people sell religious objects as though they were profane - and they know that they will be profaned. They sell their celebrations, their ceremonies: they become a spectacle in order to get money from tourists....At the end of the path peoples present the roots of their own past as a folklore show, with the illusion that they are descendants of their ancestors.

Today it is clear that not only economic reduction drives globalization. Steger (2008:98ff) notes that there are religious, cultural, technological and other reductions that perpetuate globalization. As an alternative, irreducibility can provide a balanced perspective on the advantages and disadvantages of globalization and South Africa's location within the global village (Goudzwaard, 2011:357-371). The advantages of globalization are clear from the economic growth it stimulates, the proliferation of knowledge, technological advancement and expansive global business networks. However, this has to be viewed in relation to reductionist forces that may lead to various forms of oppression like economic exploitation, cultural imperialism and environmental damage. Although globalization does have many benefits the problem is that when one aspect becomes encompassing, at the cost of others, the terror of reductionism can erase these benefits. Then, for example, globalization as an economic reduction can become a tool of multi-national companies to commoditize culture, control developing nations and destroy the environment. Thus, irreducibility is an important point of reference to advance the benefits of globalization by taking the full complexity of reality into consideration.

\section{CONCLUSION}

The purpose of this study was to argue that Kuyper's sphere sovereignty had an ambiguous role in the history of South Africa specifically during the time of apartheid. This is clear in the reductionism present in the document $\mathrm{HR}$ that reduced reality to race. However, the work of Alan Boesak that celebrates the Kuyper's views as a motive for liberation from apartheid, also uses race as point of departure. This ambiguous role of Kuyper is rooted in the misinterpretation of Kuyper's notion of sphere sovereignty. Sphere sovereignty highlights the irreducibility of reality and normativity of the creational order established by God. Irreducibility is an important concern for post-apartheid South Africa. This is evident in terms of the process of reconciliation, engagement with diverse sources of knowledge, resistance to nationalist ideologies, cultural criticism and globalization, amongst others. 


\section{REFERENCES}

Bax, D., 1983, 'The Bible and apartheid 2', in De Gruchy, J.W. \& Villa-Vicencio, C. (ed), Apartheid is a heresy, p.117, David Philip, Cape Town.

Boesak, A., 1977, Farewell to Innocence: A social-ethical study of black theology and black power, Ravan Press, Johannesburg.

Boesak, A., 1984, Black and Reformed: Apartheid, Liberation and the Calvinist Tradition, Skotaville Publishers, Johannesburg.

Botman, H.R., 2000, "Is Blood Thicker than Justice? The Legacy of Abraham Kuyper for Southern Africa." In L. Lugo (ed), Religion, Pluralism, and Public Life, MI: Eerdmans, Grand Rapids Michigan.

Calvin, J., 1948, Commentaries on the First Book of Moses called Genesis, Translated Rev John King, WM. B. Eerdmans Publishing Company, Grand Rapids Michigan

Comblin, J., 1998, Called for Freedom: The Changing Context of Liberation Theology, Maryknoll Orbis Books, New York.

Deist, F., 1994, Ervaring, Rede en Metode in Skrifuitleg: 'n Wetenskaphistoriese ondersoek na Skrifuitleg in die Ned. Geref. Kerk 1840-1990, Raad van Geesteswetenskaplike Navorsing, Pretoria.

Dooyeweerd, H. 1979. Roots of Western culture. Pagan, Secular and Christian options, Translated by J. Kraay, Wedge Publishing Foundation, Toronto.

Dutch Reformed Church, 1976, Human Relations and the South African Scene in the Light of Scripture, National Book Printers Ltd, Cape Town.

Geertsema, H.G. 1987, 'Christian philosophy: transformation or inner reformation' Philosophia Reformata, 52(2):139-165.

Goudzwaard, B., 2011, 'The principle of sphere-sovereignty in a time of Globalization', Koers, 76(2):357-371.

Kinghorn, J., 1986, Vormende Faktore. Die NG Kerk en Apartheid, Sigma-Pers Bpk, Pretoria.

Kuyper, A., 1909, De leer der Verbonden. Stichtelijke Bijbelstudien, J.H. Kok, Kampen.

Kuyper, A., 1943, Calvinism. Six Stone Foundation Lectures, WMB. Eerdmans Publishing Company, Michigan.

Kuyper, A., 1956, 'Soevereiniteit in eigen kring', in De Gaay Fortman, W.F., (ed), Architectonische critiek: fragmenten uit de social-politieke geschriften van $\operatorname{Dr} A$ Kuyper, p.41, Paris, Amsterdam.

Loubser, J.A., 1987, The Apartheid Bible: A critical review of racial theology in South Africa, Maskew Miller Longman, Cape Town.

Mouw, R.J., 2009, 'Calvin's Legacy for Public Theology', Political Theology, 10.3 (2009), 431-446.

Naudé, P., 2005, 'From pluralism to ideology: The roots of apartheid theology in Abraham Kuyper, Gustav Warneck and Theological pietism', Scriptura 88, 161-173.

Steger, M.B., 2009, Globalisation: a very short introduction, Oxford University Press, Oxford.

\section{Acknowledgements}

\section{Competing interests}

The author declares that he has no financial or personal relationship(s) that may have inappropriately influenced him in writing this article. 